\title{
Rapamycin prevents bronchiolitis obliterans through increasing infiltration of regulatory $B$ cells in a murine tracheal transplantation model
}

\author{
Yunge Zhao, MD, PhD, Jacob R. Gillen, MD, Akshaya K. Meher, PhD, Jordan A. Burns, BS,
} Irving L. Kron, MD, and Christine L. Lau, MD, MBA

\begin{abstract}
Objective: B lymphocytes are generally considered to be activators of the immune response; however, recent findings have shown that a subtype of B lymphocytes, regulatory B lymphocytes, play a role in attenuating the immune response. Bronchiolitis obliterans remains the major limitation to modern-day lung transplantation. The role of regulatory B lymphocytes in bronchiolitis obliterans has not been elucidated. We hypothesized that regulatory B lymphocytes play a role in the attenuation of bronchiolitis obliterans.
\end{abstract}

Methods: We performed a standard heterotopic tracheal transplant model. Tracheas from Balb/c mice were transplanted into C57BL/6 recipients. Rapamycin treatment and dimethyl sulfoxide control groups were each treated for the first 14 days after the transplant. Tracheas were collected on days 7, 14, and 28 post-transplantation. Luminal obliteration was evaluated by hematoxylin-eosin staining and Picrosirius red staining. Immune cell infiltration and characteristics, and secretion of interleukin-10 and transforming growth factor- $\beta 1$ were accessed by immunohistochemistry. Cytokines and transforming growth factor- $\beta 1$ were measured using the Luminex assay (Bio-Rad, Hercules, Calif).

Results: The results revealed that intraperitoneal injection of rapamycin for 14 days after tracheal transplantation significantly reduced luminal obliteration on day 28 when compared with the dimethyl sulfoxide control group $(97.78 \% \pm 3.63 \%$ vs $3.02 \% \pm 2.14 \%, P<.001)$. Rapamycin treatment markedly induced regulatory B lymphocytes (B220 $\left.{ }^{+} \mathrm{IgM}^{+} \mathrm{IgG}^{-} \mathrm{IL}-10^{+} \mathrm{TGF}-\beta 1^{+}\right)$cells when compared with dimethyl sulfoxide controls. Rapamycin treatment inhibited interleukin- $1 \beta, 6,13$, and 17 on days 7 and 14 . Rapamycin also greatly increased interleukin- 10 and transforming growth factor- $\beta 1$ production in B cells and regulatory T lymphocytes infiltration on day 28 .

Conclusions: Mammalian target of rapamycin inhibition decreases the development of bronchiolitis obliterans via inhibition of proinflammatory cytokines and increasing regulatory B lymphocytes cell infiltration, which subsequently produces anti-inflammatory cytokines and upregulates regulatory $\mathrm{T}$ lymphocyte cells. (J Thorac Cardiovasc Surg 2016;151:487-96)

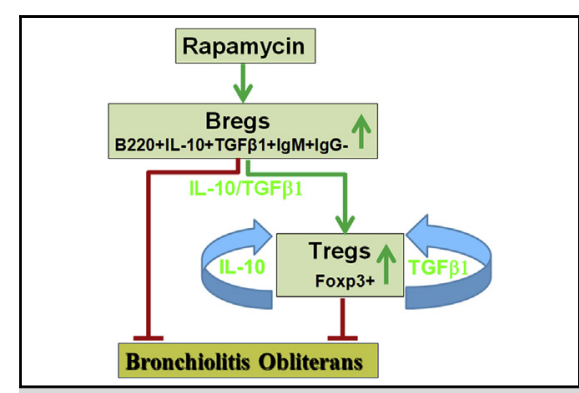

The novel inhibitory mechanism of rapamycin on BO development. Bregs, Regulatory B lymphocytes; IL, interleukin; $I g$, immunoglobulin; TGF- $\beta 1$, transforming growth factor beta 1; Tregs, regulatory T lymphocytes.

\section{Central Message}

Rapamycin inhibited BO development by increasing Breg infiltration, which secretes IL10 and TGF- $\beta 1$ production and promotes Tregs.

\section{Perspective}

Accumulated data have shown that Bregs suppress the immune treatment. Bregs/Tregs and their secreted anti-inflammatory cytokines may be used as diagnostic and prognostic markers for BO diagnosis and treatment. Promoting Bregs may be a potential new targeted treatment for patients with $\mathrm{BO}$

See Editorial Commentary page 497

See Editorial page 317.
From the Division of Thoracic and Cardiovascular Surgery, Department of Surgery, University of Virginia, Charlottesville, Va.

ILK is supported by T32HL007849. CLL is supported by a grant sponsored by the National Heart, Lung, and Blood Institute (1K08HL094704-01) and The Advancing Research in Transplantation Science 2011 Grant Program from Pfizer (WS2331368).

Read at the 95th Annual Meeting of The American Association for Thoracic Surgery, Seattle, Washington, April 25-29, 2015.

Received for publication May 1, 2015; revisions received July 6, 2015; accepted for publication Aug 11, 2015; available ahead of print Oct 16, 2015.

Address for reprints: Christine L. Lau, MD, MBA, Department of Surgery, PO Box 800679, Charlottesville, VA 22908-0679 (E-mail: cl12y@virginia.edu). 0022-5223/\$0.00

Published by Elsevier Inc. on behalf of The American Association for Thoracic Surgery

http://dx.doi.org/10.1016/j.jtcvs.2015.08.116
Lung transplantation is currently recognized as the preferred treatment for patients with end-stage pulmonary diseases. The long-term mortality of lung recipients is highest among all solid organs transplanted. The Achilles' heel of lung

Scanning this QR code will take you to supplemental figures for this article. To view the AATS 2015 Webcast, see the URL at the end of the article. 


$$
\begin{aligned}
& \text { Abbreviations and Acronyms } \\
& \begin{aligned}
\text { BO } & =\text { bronchiolitis obliterans } \\
\text { Bregs } & =\text { regulatory B lymphocytes } \\
\text { DMSO } & =\text { dimethyl sulfoxide } \\
\text { Foxp3 } & =\text { forkhead box protein } 3 \\
\text { HTT } & =\text { heterotopic tracheal transplant } \\
\text { Ig } & =\text { immunoglobulin } \\
\text { IL } & =\text { interleukin } \\
\text { TGF } & =\text { transforming growth factor } \\
\text { Tregs } & =\text { regulatory T lymphocytes }
\end{aligned}
\end{aligned}
$$

transplantation remains chronic allograft rejection. ${ }^{1-3}$ Histologically, chronic lung allograft rejection is seen as small airway obliteration known as "bronchiolitis obliterans" (BO).$^{3-5}$ Because BO is difficult to detect after lung transplantation on transbronchial biopsies, it is commonly referred to as a syndrome characterized in the recipient as a progressively decline in pulmonary function. Most patients die of respiratory failure within 5 years of onset.

We and others have used a preclinical well-described mouse heterotopic tracheal transplant (HTT) model to better understand the mechanisms involved in $\mathrm{BO}^{6-9}$ Our previous reports showed that a short course treatment of rapamycin, a macrocyclic triene antibiotic pro-drug, prevented the development of BO through 2 different mechanisms in an HTT model: (1) reducing fibrocyte recruitment to the tracheal allografts ${ }^{10}$ and (2) protecting against airway epithelium loss and promoting epithelial progenitor cells. ${ }^{11}$ During these studies, we appreciated that despite rapamycin significantly reducing $\mathrm{BO}$ development, it simultaneously increased cell infiltration into the allografts. This surprising finding led us to ask the following questions: What are these infiltrated cells? What is the function of these cells?

It is known that rapamycin is a clinically used immunosuppressant that inhibits the activity of $\mathrm{T}, \mathrm{B}$, and natural killer cells. B cells can activate the immune system through producing antigen-specific antibodies and inducing optimal T-cell activation. ${ }^{12,13}$ B-cell activation has been reported ${ }^{12,13}$ as the cause of antibody-mediated rejection after organ transplantation, also known as "hyperacute rejection." Thus, B cells have been linked to decreased allograft survival. However, accumulated data suggest that $\mathrm{B}$ cells can also downregulate the immune response. This downregulation is a result of production of anti-inflammatory cytokines. ${ }^{14-22}$ Although much remains unknown about the role that regulatory $\mathrm{B}$ lymphocytes (Bregs) play in suppression of the immune response, it is broadly accepted these cells exist and contribute to the immune response attenuation. ${ }^{23,24}$ Among the variety of Breg subsets that have been described, interleukin (IL)-10-producing Breg cells (B10 cells) are the most widely studied Breg cell subset. $^{22,23,25}$ In addition, Bregs may increase the differentiation of regulatory $\mathrm{T}$ lymphocytes (Tregs) through secretion of anti-inflammatory cytokine, IL-10, and transforming growth factor (TGF)- $\beta 1 .{ }^{26}$ We hypothesize that the suppressive effects of rapamycin are at least partly due to Breg infiltration into the allograft and subsequently increase Tregs to prevent BO development. This may provide a previously unknown mechanism of action of rapamycin in lung transplantation rejection.

In the current study, we show that intraperitoneal injection of rapamycin significantly increased Breg cell $\left(\mathrm{B} 220^{+} \mathrm{IgM}^{+} \mathrm{IgG}^{-} \mathrm{IL}-10^{+}\right.$TGF- $\left.\beta 1^{+}\right)$and forkhead box protein 3 (Foxp3) ${ }^{+}$Treg infiltration into the allografts in a mouse HTT model. The results indicate that both these types of cells infiltrating into the grafts result in the prevention of BO development. Therefore, understanding how Bregs infiltrate into allografts and their potential functions may provide novel ways to prevent $\mathrm{BO}$ and improve lung transplant success.

\section{MATERIALS AND METHODS}

\section{Animals}

Balb/c and C57BL6 male mice were purchased from Jackson Laboratory (Bar Harbor, Me). All the experimental mice received humane care in accordance with the "Principles of Laboratory Animal Care," formulated by the National Society for Medical Research, and "The Guide for the Care and Use of Laboratory Animals," prepared by the National Academy of Science and published by the National Institutes of Health. The study protocol was fully reviewed and approved by the Animal Care and Use Committee at the University of Virginia before experimentation.

\section{Mouse Model of Heterotopic Tracheal Transplant}

The mouse HTT model of BO was performed according to our previous publications. ${ }^{6,7,27,28}$ Briefly, an MHC class I and II mismatch was produced by transplanting Balb/c $\left(\mathrm{H}-2^{\mathrm{d}}\right)$ tracheas into the $\mathrm{C} 57 \mathrm{BL} / 6$ mice $\left(\mathrm{H}-2^{\mathrm{b}}\right)$.

\section{Experimental Group Design}

Experimental mice were divided into 4 groups: (1) Balb/c tracheas transplanted into C57BL/6, treated with rapamycin at dosage of $5 \mathrm{mg} / \mathrm{kg} / \mathrm{d}$ for the first 2 weeks; (2) Balb/c tracheas transplanted into C57BL/6, treated with rapamycin at dosage of $10 \mathrm{mg} / \mathrm{kg} / \mathrm{d}$ for the first 2 weeks; (3) Balb/c tracheas transplanted into $\mathrm{C} 57 \mathrm{BL} / 6$, treatment with dimethyl sulfoxide (DMSO) for the first 2 weeks serving as controls; (4) C57BL/6 tracheas transplanted into C57BL/6 serving as isograft controls. In all groups, 4 donor tracheas were transplanted into 1 recipient; 6 recipients were used in each group and each time point. On days 7, 14, and 28 days after transplantation, the isograft and allografts were collected for histology, Luminex assay (Thermo Fisher Scientific Inc, Waltham, Mass), and immunohistochemical staining.

\section{Histology}

The transplanted tracheas were collected and immediately fixed in $4 \%$ zinc-formalin. After 24 hours, they were embedded in paraffin and sectioned and stained with hematoxylin-eosin or underwent immunohistochemical staining. 


\section{Immunohistochemical Staining of Macrophages and Neutrophils}

Macrophages and neutrophils were detected by immunohistochemical analysis as described previously. ${ }^{6,7,27,28}$ Briefly, rat anti-mouse neutrophil (AbD Serotec, Raleigh, NC) and rat anti-mouse macrophage (Mac-2, Accurate Chem, Westbury, NY) antibodies were used as primary antibodies. Alkaline phosphatase-conjugated anti-rat immunoglobulin (Ig)G (Sigma, St Louis, Mo) was used as a secondary antibody. Fast-Red (Sigma) was used as a substrate. Purified normal rat IgG (eBioscience Inc, San Diego, Calif) was used as a negative control. The sections were counterstained lightly with hematoxylin for viewing negatively stained cells.

\section{Immunohistochemical Staining of CD3 + T Cells, B Cells, Regulatory B Lymphocytes, and Regulatory $T$ Lymphocytes}

The staining was performed according to our previous publications. $6,7,27,28$ Briefly, the slides were deparaffinized, dehydrated antigen unmasked, and blocked. Then the following primary antibodies were applied: goat anti-mouse CD $3 \varepsilon$ antibody (Santa Cruz Biotechnology, Dallas, Tex) for T cells, rat anti-mouse B220 (BD Pharmingen, San Diego, Calif) for B cells, rat anti-mouse IL-10 (BioLegend, San Diego, Calif), rabbit anti-mouse TGF- $\beta 1$ (LifeSpan Biosciences, Inc, Seattle, Wash), and rabbit anti-mouse Foxp3 (Abcam Inc, Cambridge, Mass). After incubation with an avidin-biotin complex, immunoreactivity was visualized by incubating the sections with 3, 3-diaminobenzidine tetrahydrochloride (Dako Corp, Carpinteria, Calif) to produce a brown precipitate and then counterstained with hematoxylin. The number of positive staining cells per high power field was assessed by the Photoshop (Adobe, San Jose, Calif) counting tool, and at least 5 fields were counted per trachea by blinded observers. The average cell number was used for statistical analysis.

\section{Double Immunofluorescence Staining of Immunoglobulin-M and $\mathbf{G}$}

The slides were prepared as described earlier. The primary antibodies are goat anti-mouse IgM (Acris, San Diego, Calif) and Alexa Fluor 488 conjugated rabbit anti-mouse IgG (Invitrogen, Carlsbad, Calif). The secondary antibody for IgM was alkaline phosphatase-conjugated donkey anti-goat IgG (Sigma, St. Louis, Mo). The substrate was Fast Red (Sigma, St. Louis, Mo). Purified pre-immune IgGs from the same animal species were used as negative controls. The cell nucleus was stained with DAPI (Roche Diagnostics, Mannheim, Germany). Images were viewed and saved using an Olympus BX51 microscope equipped with an Olympus DP70 digital camera (Olympus Corp, Minneapolis, Minn).

\section{Measurement of Luminal Obliteration}

The degree of luminal obliteration on day 28 after transplantation was evaluated according to our previous publications. ${ }^{6,7,27,28}$ Briefly, allografts were photographed at $4 \times$ magnification, and the area of the obliterated lumen and the total area of lumen were measured using the Image-Pro Plus software (Media Cybernetics, Inc, Rockville, Md). The percent of the obliteration was calculated by the area of the fibrosis divided by the total area of lumen. Eight to 10 allografts were measured in each group. The data were used for statistical analysis.

\section{Protein Extraction and Bio-Plex Cytokine Analysis}

The allografts and isografts were weighed and trimmed by scissors. After being mixed with 10 volumes of $1 \times$ phosphate-buffered saline, the mixture were loaded into Lysing Matrix D (MP Biomedicals, Santa Ana, Calif) tubes and homogenized in an MP fast prep machine for 30 seconds twice. Then the samples were centrifuged at $3000 \mathrm{rpm}$ at $4^{\circ} \mathrm{C}$ for $10 \mathrm{mi}-$ nutes. The supernatant was collected for Bio-Plex (Bio-Rad, Hercules, Calif) cytokine analysis. The cytokine analysis was performed according
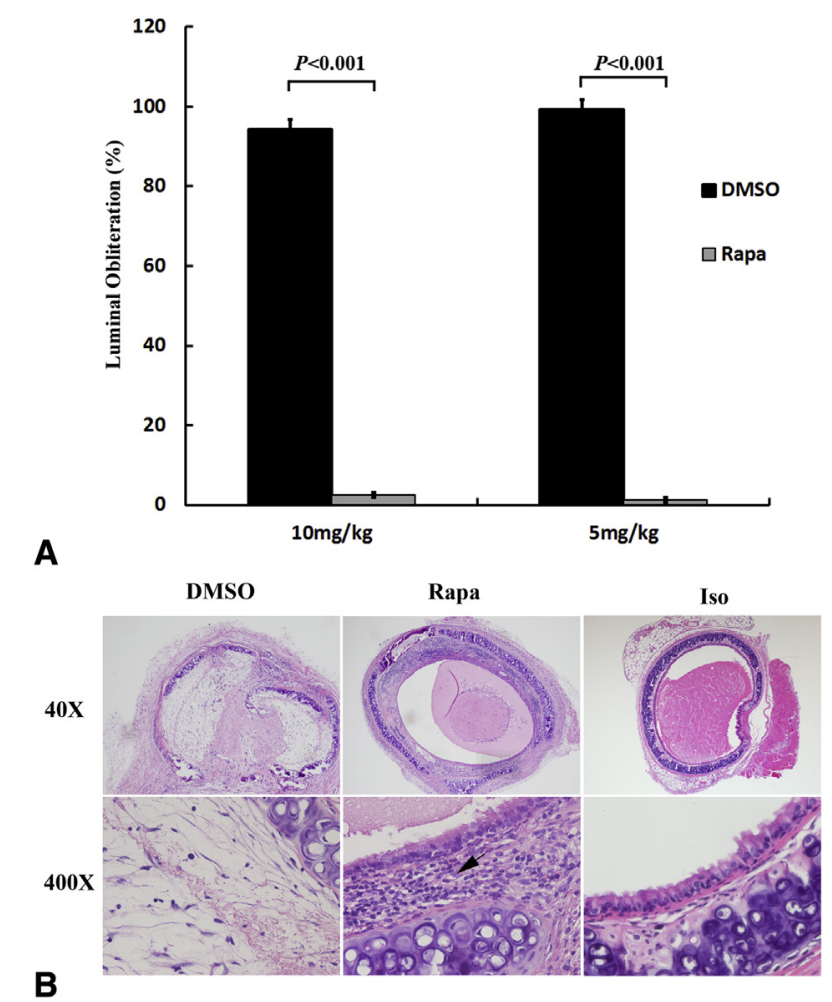

FIGURE 1. Rapamycin treatment reduces luminal obliteration but increases cell infiltration. A, Intraperitoneal injection of rapamycin significantly reduced luminal obliteration of the allografts on day 28 after tracheal transplantation. Data shown are the mean \pm standard error, $\mathrm{n}=6$. B, Representative pictures of cellular infiltration in the allografts and isograft controls from 28 days post-transplantation. The magnification of all the pictures was $40 \times$ and $400 \times$. Black arrow indicates infiltrated cells. The donors are Balb/c mice, and the recipients are $\mathrm{C} 57 \mathrm{BL} / 6$ mice. C57BL/6 to C57BL/6 isograft controls are also performed. DMSO, Dimethyl sulfoxide; Rapa, rapamycin; Iso, isograft.

to the manufacturer's instruction in the Bio-Plex 200 system (Bio-Rad) using a Bio-Plex Pro mouse cytokines standard 23-Plex Group I kit and Bio-Plex Pro TGF- $\beta$ Standard 3-Plex kit.

\section{Statistical Analysis}

Data are presented as the mean \pm standard error of the mean. The B cells, Bregs, and Tregs were compared using 1-way analysis of variance followed by the Student $t$ test for unpaired data with Bonferroni correction. Square roots of tissue cell counts were compared using 1-way analysis of variance.

\section{RESULTS}

\section{Rapamycin Treatment Significantly Reduced Tracheal Luminal Obliterations but Increased Cell Infiltration}

By using a mouse HTT model (Balb/C trachea as donor and wild-type C57BL/6), we were able to observe the effects of rapamycin on the histologic kinetics of allografts post-transplantation from the different groups and different time points. The results revealed that rapamycin at 2 different concentrations (5 mg/kg/d and $10 \mathrm{mg} / \mathrm{kg} / \mathrm{d}$ ) 


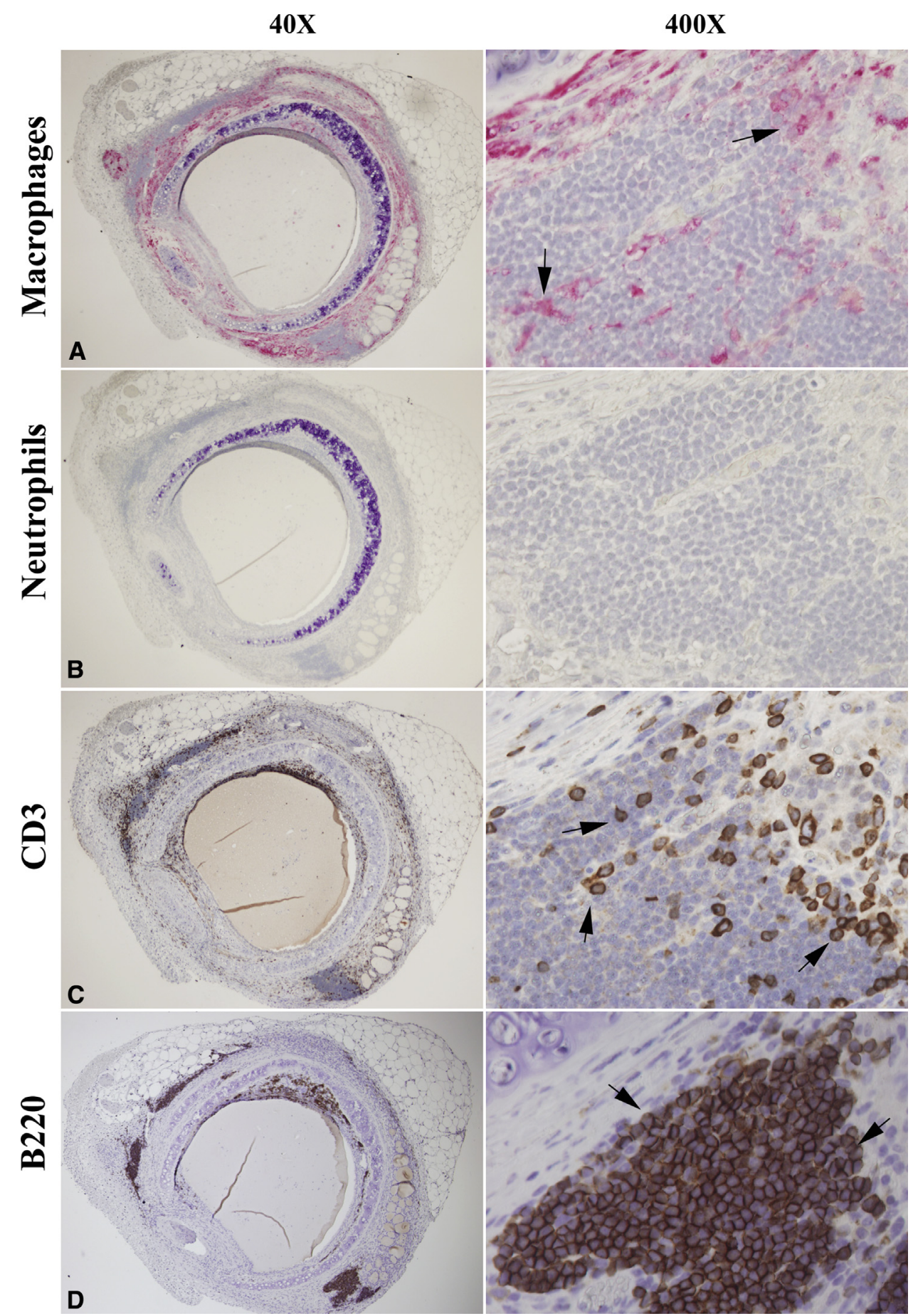

FIGURE 2. Immunohistochemical staining of macrophages, neutrophils, $\mathrm{CD}^{+} \mathrm{T}$ cells, and $\mathrm{B} 220^{+} \mathrm{B}$ cells in the rapamycin-treated (10 mg/kg/d) allografts on day 28 after tracheal transplantation. A-D, Representative immunostaining picture of macrophage, neutrophils, $\mathrm{CD}^{+} \mathrm{T}^{+}$cells, and $\mathrm{B} 220^{+}$ B cells, respectively. Red color/solid arrows indicate positive staining cells in A and B. Brown/dark brown/solid arrows indicate T and B cells in C and D. All sections were counterstained lightly with hematoxylin for viewing negatively stained cells. The magnifications are indicated.

significantly inhibited luminal obliterations when compared with DMSO control groups on day 28 after tracheal transplantation (Figure 1, A). However, the 2 drug dosages did not show a significant difference between one another. These results indicate that the lower dosage $(5 \mathrm{mg} / \mathrm{kg} / \mathrm{d})$ was sufficient for luminal obliteration. Rapamycin (both dosages) treatment also increased cell infiltration into the allografts when compared with DMSO control groups on days 14 and 28 after tracheal transplantation (Figure 1, $B)$. The infiltrated cells were found in various forms, and 
they could distribute evenly or cluster together (Figures 1, $B$, and 2).

\section{The Major Infiltrated Cells Were B Cells}

To better characterize these infiltrated cells, immunohistochemical staining with antigen-specific antibodies was used. Among these cells, neutrophils were not identified at all; only a small portion were $\mathrm{Mac}-2^{+}$macrophages and $\mathrm{CD}^{+} \mathrm{T}$ cells (Figure 2, $A-C$ ). We found that the majority of the infiltrated cells were B220 ${ }^{+} \mathrm{B}$ cells (Figure 2, D). After counting the $\mathrm{B} 220^{+} \mathrm{B}$ cells in the rapamycin-treated (10 mg/kg/d) group, DMSO control group, and isograft controls, we confirmed that B cells were markedly elevated in the rapamycin-treated groups (Figure 3, $A$ and $B$ ). The lower-dosage rapamycin $(5 \mathrm{mg} / \mathrm{kg} / \mathrm{d})$ treatment also significantly elevated B cells when compared with DMSO controls $(196.3 \pm 50.0$ vs $2.4 \pm 1.7)$.

\section{The Majority of the Infiltrated B Cells Were IgM $^{+}$IgG $^{-}$IL-10 ${ }^{+}$TGF- $\beta 1^{+}$Regulatory B Lymphocytes}

To further determine the subset of these infiltrated B cells, conventional immunohistochemistry and double immunofluorescence staining were used. The results showed that almost all the $\mathrm{B}$ cells were $\operatorname{IgM}^{+}$cells, whereas none of them produced IgG (Figure 4, A). The majority of these cells were also $\mathrm{IL}-10^{+}$and $\mathrm{TGF}-\beta 1^{+}$cells (Figure $4, B$ ), which suggested that these cells were B220 ${ }^{+} \operatorname{IgM}^{+} \mathrm{IgG}^{-} \mathrm{IL}_{-10}{ }^{+}$TGF- $\beta 1^{+}$Bregs. Statistical analysis showed that rapamycin significantly increased IL-10 ${ }^{+}$ cells when compared with DMSO controls $(P<.001)$ (Figure 5, A), although TGF- $\beta 1$-positive cells showed no significant difference between the rapamycin treatment and DMSO controls $(P=.147$ ) (Figure 5, $B)$. Our study also showed that TGF- $\beta 1$ was mainly expressed in the $B$ cells in the rapamycin-treated grafts, but extensively expressed in fibrotic cells in the entire lumen of DMSO controls (Figure E1). We suggest that these Bregs (at least partially) are derived from the spleens of these animals because the size of the rapamycin-treated spleens was smaller and the numbers of Bregs in the rapamycintreated spleens were decreased (Figure E2).

\section{Bio-Plex Assay of Cytokines}

The Luminex assay showed that rapamycin treatment significantly inhibited proinflammatory cytokines, including IL-1 $\beta$, IL-6, IL-13, and IL-17, when compared with DMSO controls on days 7 and 14. Furthermore, rapamycin also greatly increased the levels of anti-inflammatory cytokines, IL-10 and IL-4, in the allografts on day 28 (Figure $6, A$ and $B$ ). The activated TGF- $\beta 1$ production in the rapamycin-treated groups was decreased when compared with DMSO controls $(18,034.5 \pm 1978 \mathrm{pg} / \mathrm{mL}$ vs $37,405.0 \pm 3012 \mathrm{pg} / \mathrm{mL}$ ), but increased when compared

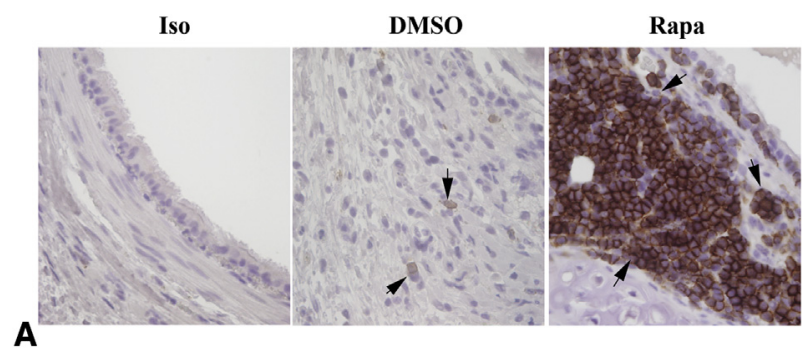

A

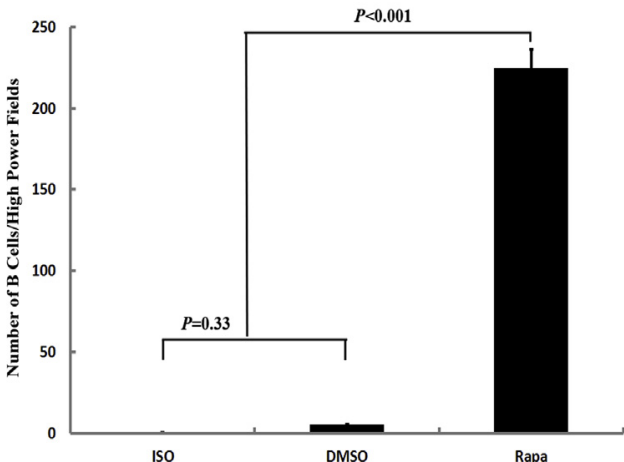

FIGURE 3. Increasing of $\mathrm{B} 220^{+} \mathrm{B}$ cells in rapamycin-treated allografts on day 28 post-transplantation. A, Representative pictures of B220 staining in the allografts and isograft controls from 28 days post-transplantation. Brown color/solid arrows indicate $\mathrm{B} 220^{+}$cells. The magnification is $400 \times$. B, Comparison of $\mathrm{B} 220^{+}$B-cell infiltration in the rapamycintreated allograft with the isograft and DMSO control allografts on day 28 post-transplantation. Data shown are the mean \pm standard deviation $\mathrm{n}=6$. Iso, Isograft; DMSO, dimethyl sulfoxide; Rapa, rapamycin.

with isograft groups $(18,034.5 \pm 1978 \mathrm{pg} / \mathrm{mL}$ vs $8599 \pm 1453 \mathrm{pg} / \mathrm{mL}$ ) on day 28 (Figure E3).

\section{FoxP3 + Regulatory T Cells Were Significantly Elevated in the Rapamycin-Treated Groups}

Because Bregs secrete anti-inflammatory cytokine IL-10 and TGF- $\beta 1$, which subsequently stimulate Tregs generation, ${ }^{26}$ we further tested Tregs in our experimental groups. The results showed that rapamycin treatment (both dosages) significantly increase Tregs when compared with DMSO controls (Figure 7).

\section{DISCUSSION}

The mouse HTT model of BO described in this study displays several features that are similar to human $\mathrm{BO}^{5,29}$ and is a well-established research model. Heterotopic tracheas transplanted into human leukocyte antigens in mismatched recipients develop injury that can be divided into an acute phase (days 1 to 3 ), a later phase (days 4 to 12), and a fibro-obliteration phase (days 13 to 28). The current studies in our laboratory have focused on the role played by fibrocytes (early progenitor cells) in the development of $\mathrm{BO}$. We have found (through CXCR4-CXCL12 pathways) that rapamycin prevents the influx of fibrocytes into the allografts and attenuates BO development. As a result of these studies, 

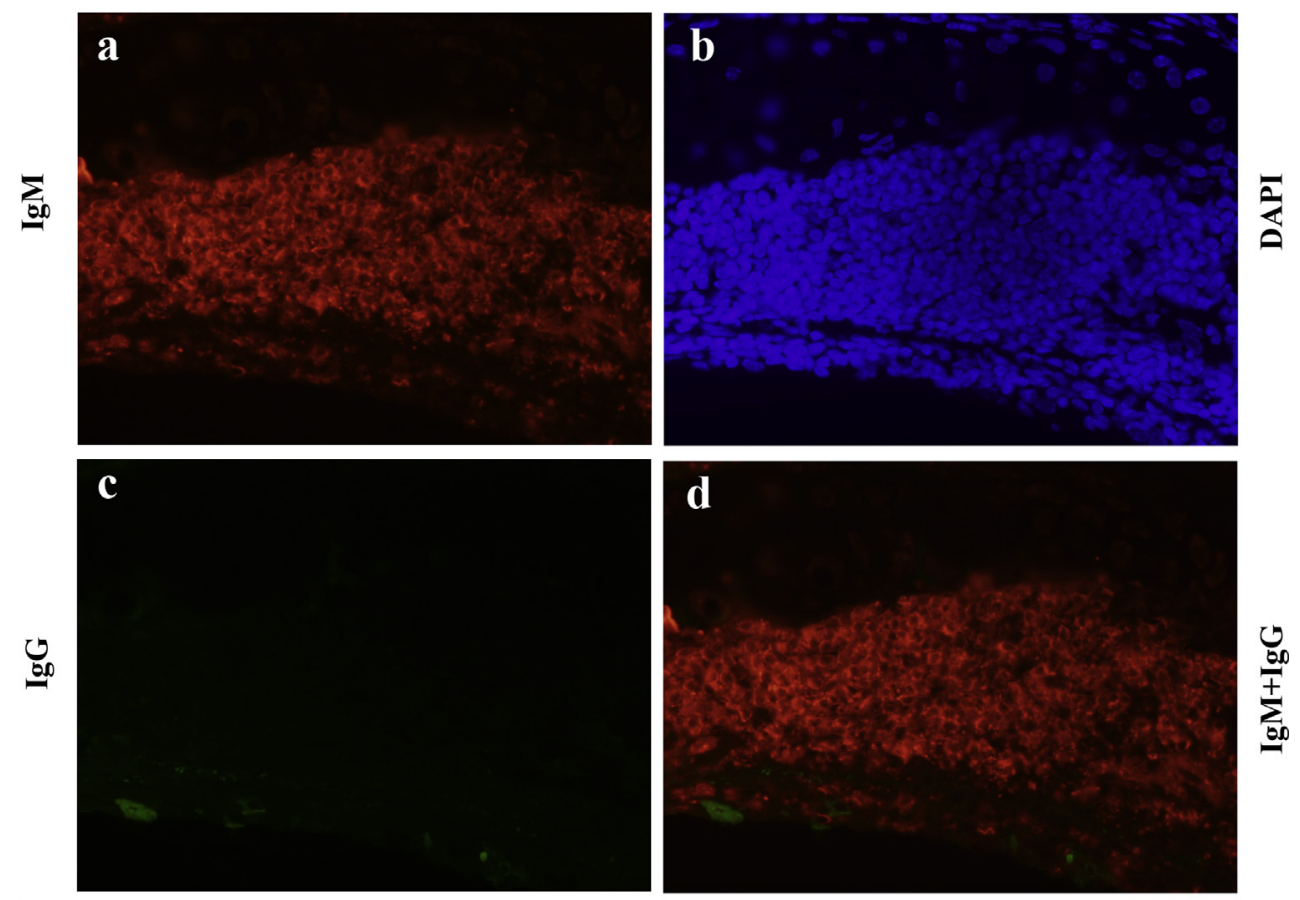

A
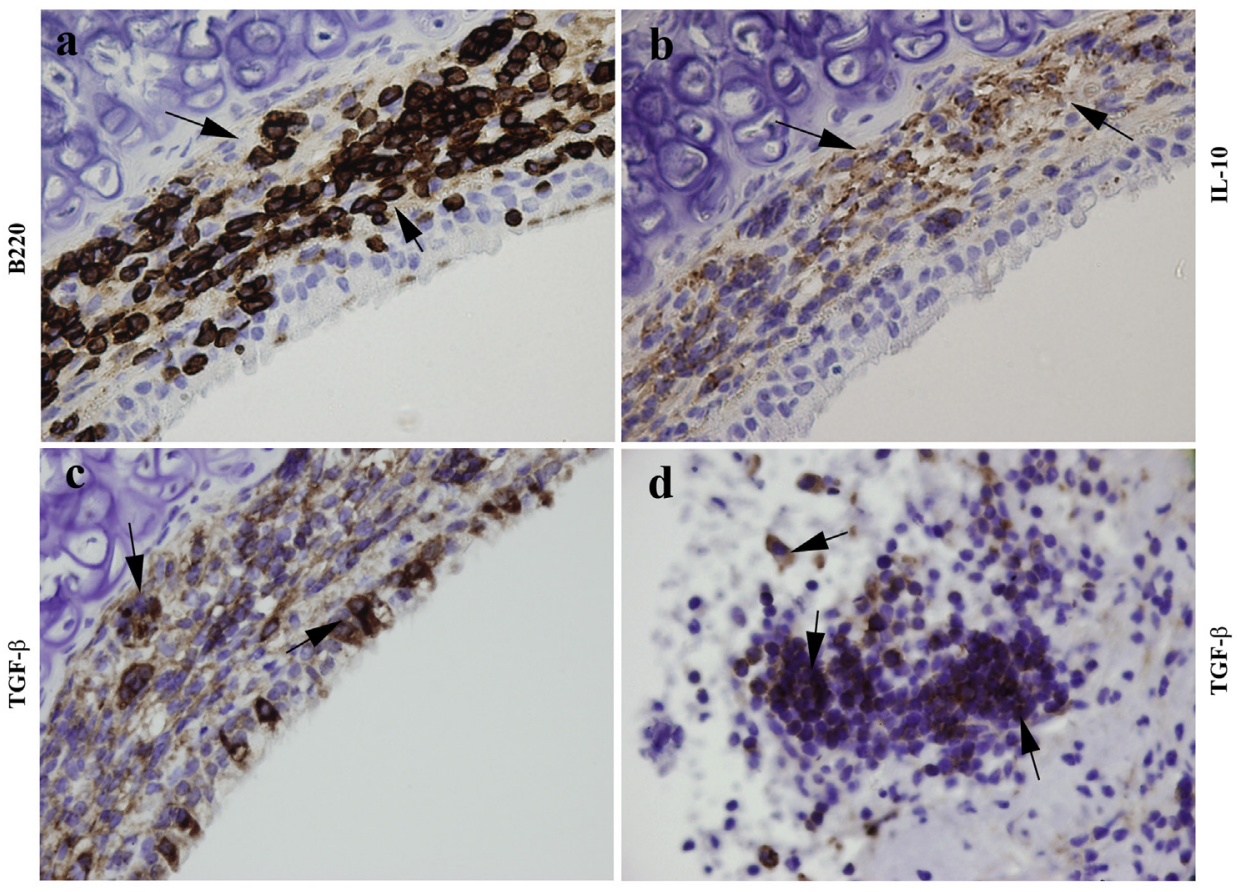

FIGURE 4. Identification of B220, IL-10, IgM, and TGF- $\beta 1$-positive regulatory B cells in the rapamycin-treated allografts on day 28 post-transplantation. A, Double immunofluorescence staining of $\operatorname{IgM}$ and IgG in the rapamycin-treated allografts on day 28. Red indicates IgM-positive B cells in A-a and A-d. Green indicates IgG-positive B cells in A-c and A-d. Blue is DAPI staining for viewing negative staining cells in A-b and A-d. B, Representative immunohistochemical staining of B220, IL-10, and TGF- $\beta 1$ in the rapamycin-treated allografts. Cells stained brown indicate positive staining cells. The arrows indicate $\mathrm{B} 220^{+}$cells in B-a, IL- $10^{+}$cells in B-b, and TGF- $\beta 1^{+}$cells in B-c and -d. The magnifications are $400 \times$ in all pictures. Ig, Immunoglobulin; $I L$, interleukin; $T G F$, transforming growth factor.

we found other immune cells concentrating in the allografts of these treated animals. The majority of these cells were subsequently determined to be Bregs. To our knowledge, this is the first report of the role of Bregs in $\mathrm{BO}$ attenuation.
Rapamycin is a relatively new immunosuppressant drug that functions as a serine/threonine kinase inhibitor to prevent rejection in organ transplantation. The full mechanism of rapamycin's immunosuppression is still under 

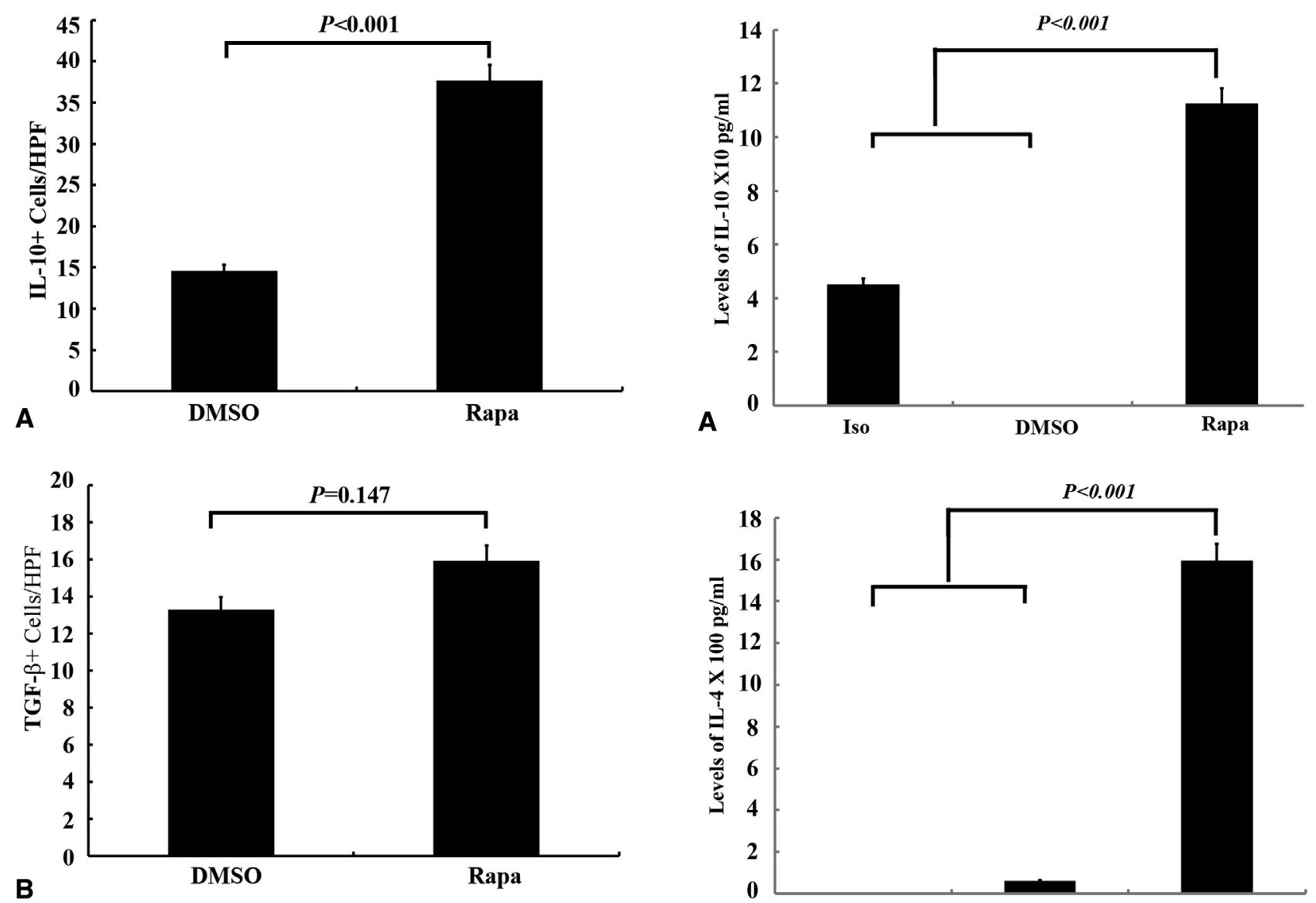

FIGURE 5. Comparison of effects of rapamycin on IL- $10^{+}$(A) and TGF$\beta 1^{+}$(B) cells in the allografts with DMSO controls on day 28. The number of positive staining cells per high-power field was assessed by the Photoshop (Adobe, San Jose, Calif)) counting tool, and at least 5 fields were counted per trachea. Data shown are the mean \pm standard deviation, $\mathrm{n}=6 . I L$, Interleukin; $H P F$, high-power field; $D M S O$, dimethyl sulfoxide; $R a p a$, rapamycin; $T G F$, transforming growth factor.

exploration. When we study the effects of rapamycin on BO development through inhibiting fibrocyte recruitment ${ }^{10}$ and promoting epithelial progenitor cell regeneration, ${ }^{11}$ an unexpected finding was seen that rapamycin significantly reduced luminal obliteration, but markedly increased cellular infiltration in the allografts on days 14 and 28 . We and others have reported that the cellular infiltration peaked on day 7 , and then the inflammatory cells gradually decreased to base levels. ${ }^{6,7,27,28}$ In this study, we discovered that rapamycin prevented luminal obliteration after tracheal transplantation and that Bregs infiltrated into the allografts, indicating their involvement in $\mathrm{BO}$ attenuation. This finding suggests new mechanisms of $\mathrm{BO}$ development and prevention. Breg-targeted therapy may open a new window for BO treatment.

In organ transplantation, the composition of the B-cell compartment is increasingly identified as an important determinant for graft outcome. Naïve and transitional

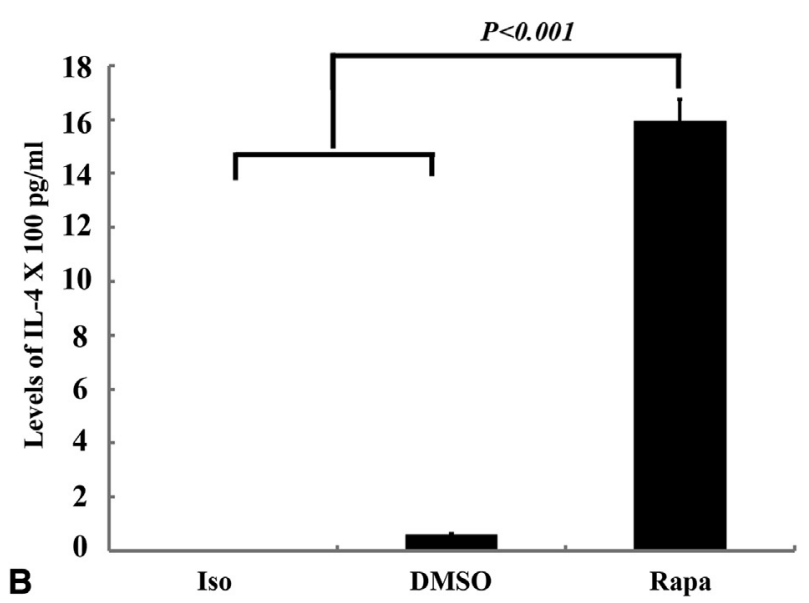

FIGURE 6. Levels of IL-10 (A) and IL-4 (B) in the allografts and isografts on day 28. Luminex assay (Thermo Fisher Scientific Inc, Waltham, Mass) was performed using the Bio-Plex 200 system (Bio-Rad, Hercules, Calif) with standard controls. The concentration is $\mathrm{pg} / \mathrm{mL}$. Data shown are the mean \pm standard deviation, $\mathrm{n}=6$. IL, Interleukin; Iso, isograft; DMSO, dimethyl sulfoxide; Rapa, rapamycin.

B cells have been correlated with long-term allograft survival and operational tolerance, whereas the memory $\mathrm{B}$ cells have been linked to decreased allograft survival. ${ }^{30}$ It is known that B cells are involved in regulating the immune responses through producing antibodies and inducing optimal T-cell activation. ${ }^{12,13}$ The antibody-mediated rejection after lung transplantation has been well investigated and recently reviewed by McManigle and colleagues. ${ }^{31}$ Multiple studies have demonstrated that Bregs, a distinct subset of B cells, exert significant immunoregulatory functions. ${ }^{14-17,19-22}$ For mouse Bregs, although the molecular marks of definite Bregs are still controversial, the 2 most widely accepted are Claudia Mauri's definition ${ }^{23}$ of Bregs as a subset of the transitional 2 (T2) B cells, defined as CD19 + CD21hiCD23hiIgMhiCD24hi, and Yanaba and colleagues' description $^{22}$ of B10 cells as CD19 + CD5+CD1dhi. Another obvious marker for the Bregs is the production of the immunosuppressive cytokine 


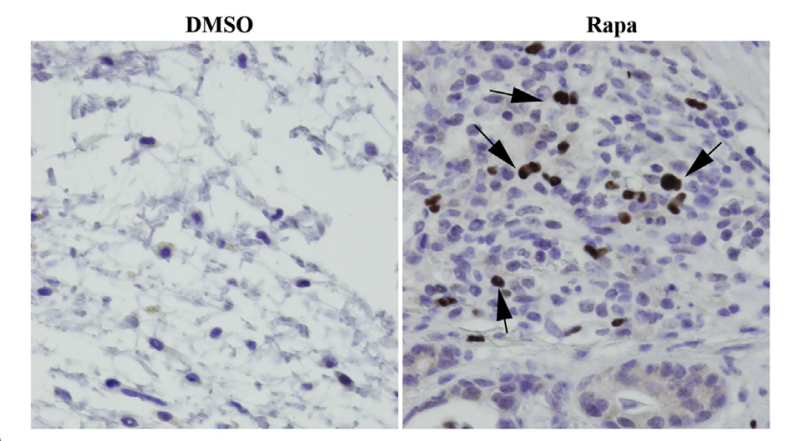

A

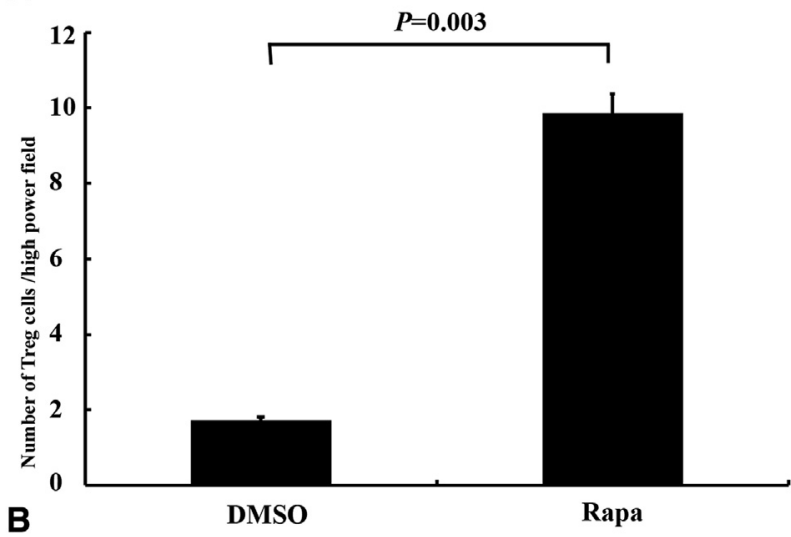

FIGURE 7. Comparison of effects of rapamycin on FoxP3 ${ }^{+}$Tregs in the allografts with DMSO controls on day 28. A, Representative immunohistochemical staining of FoxP3 ${ }^{+}$Tregs in the treated allografts. Cells stained brown indicate positive staining cells (marked by arrows). The magnifications are $400 \times$. B, Statistical analysis of Tregs in rapamycin-treated and DMSO control in the allografts. The number of positive staining cells per high-power field $(400 \times)$ was assessed by the Photoshop counting tool, and at least 5 fields were counted per trachea. Data shown are the mean \pm standard deviation, $\mathrm{n}=6 . D M S O$, Dimethyl sulfoxide; Rapa, rapamycin; Treg, regulatory T lymphocytes.

IL-10 and TGF- $\beta 1 .^{14,18,20-24,26}$ In the current study, we identified that rapamycin treatment not only significantly elevated $\mathrm{B}_{220}{ }^{+} \mathrm{IgM}^{+} \mathrm{IgG}^{-} \mathrm{B}$ cells (Figures 2-4) but also markedly spared $\mathrm{IL}-10^{+}$and TGF- $\beta 1^{+} \mathrm{B}$ cells in the allografts on days 14 and 28 after tracheal transplantation (Figures 4 and 5). The Luminex assay confirmed that the IL-10 level was highly increased in the rapamycin-treated allografts when compared with the DMSO controls (Figure 6). These results strongly indicate that rapamycin may attenuate BO through secretion of anti-inflammatory cytokine IL-10 and TGF- $\beta 1$.

Although rapamycin elevated TGF- $\beta 1$ production in the infiltrated B-cell populations, the total TGF- $\beta^{+}$cell counts had no significant difference between the rapamycin-treated allografts and DMSO controls (Figure 5, B) on day 28. Furthermore, the Luminex assay results revealed that the total latent form of TGF- $\beta 1$ had no significant difference between the rapamycin treatment group and the DMSO control groups on day 28, although both active forms of TGF- $\beta 1$ and TGF- $\beta 2$ were significantly decreased. The
TGF data from the Luminex assay seemed controversial compared with our immunohistochemical staining data. Our additional experimental data demonstrated that the high levels of TGF- $\beta 1$ in DMSO controls that originated from the various of fibrotic cells, although the main source of the TGF- $\beta 1$ in rapamycin-treated allografts, were mainly from the $\mathrm{B} 220^{+} \mathrm{B}$ cells. No fibrotic tissues were observed in the rapamycin-treated allografts, whereas few $\mathrm{B} 220^{+}$ $B$ cells were identified in the DMSO control allografts. These results suggest that the total levels of TGF- $\beta 1$ may not as important as the origination cells of this molecule. It is possible that the same TGF- $\beta 1$ molecule from different originations, in different locations, and in different environments may act differently. For example, Liu and colleagues $^{32}$ reported that TGF- $\beta 1$ promoted the production of alpha smooth muscle protein and transformation of fibroblasts into myofibroblasts through the Smad3-dependent signal pathway, thus resulting in the development of BO. Schliesser and colleagues ${ }^{33}$ demonstrated that TGF- $\beta 1$ led to an increase of CD25(+)Foxp3(+)-expressing Tregs, which are well-known inhibitory regulatory cells to immune response and results in allograft tolerance and long-term graft survival. Patients who underwent lung transplantation were normally treated with immunosuppressive agents, such as sirolimus, cyclosporine A, tacrolimus, and azathioprine for successful outcomes. ${ }^{2,34}$ On the basis of these findings, we proposed that the total level of TGF- $\beta 1$ could not be used as a biomarker to monitor the process of $\mathrm{BO}$ development after lung transplantation, but the $\mathrm{B} 220^{+} \mathrm{IGM}^{+} \mathrm{IgG}{ }^{-} \mathrm{TGF}-\beta 1^{+}$cells can be served as a useful cellular marker for the prognosis and treatment of BO.

We found that rapamycin not only elevated $\mathrm{B}_{2} 2^{+} \mathrm{IgM}^{+} \mathrm{IgG}^{-} \mathrm{IL}-10^{+} \mathrm{TGF}-\beta 1^{+}$Bregs but also significantly increased Foxp3+ Tregs, which is a subset of $\mathrm{CD} 4{ }^{+} \mathrm{CD} 25^{+} \mathrm{Foxp}^{+}$lymphocytes, and have the functional ability to suppress immune responses in vitro and in vivo. Our current findings are consistent with previous reports that rapamycin administration was also associated with an increase in Tregs. ${ }^{35-39}$ It is notable that Bregs not only can inhibit T-helper1/17-mediated immune responses but also can convert effector $\mathrm{T}$ cells into Tregs. ${ }^{39-42}$ The promotion effects of Bregs on the Tregs was mediated by IL-10 and TGF- $\beta 1{ }^{26,33,41,42}$ In addition, Schliesser and colleagues $^{33}$ proved that the addition of TGF- $\beta+$ retinoic acid or rapamycin resulted in an increase of $\mathrm{CD} 25(+)$ Foxp3(+)-expressing $\mathrm{T}$ cells, but the addition of TGF- $\beta+$ retinoic acid seemed to be superior over rapamycin in stabilizing the phenotype and functional capacity of Tregs. Thus, we suggest the possible mechanism for rapamycin-induced Tregs elevation is that rapamycin increases Bregs, which subsequently secreted IL-10 and TGF- $\beta 1$. Then these 2 molecules stimulate the conversion of T cells into Tregs in our mouse HTT model. 


\section{Study Limitations}

The HTT model of BO is a large airway model, whereas it is a small airway disease in humans. The transplanted tracheas are neither aerated nor surgically revascularized. Recent reports showed other murine models of BO, such as the orthotopic tracheal transplant model and the lung transplant model. ${ }^{43,44}$ However, these other models do not generate airway obliteration as consistently as the HTT model and are more difficult to reproduce technically. Therefore, the HTT model remains the most reliable model of BO. In addition, because the current results were obtained in a mouse $\mathrm{BO}$ model, it may be not applicable in clinics.

\section{CONCLUSIONS}

Our results indicate that Breg infiltration is a possible mechanism that prevents BO in rapamycin-treated animals. Rapamycin spares $\mathrm{B} 220^{+} \mathrm{IgM}{ }^{+} \mathrm{IgG}^{-} \mathrm{IL}-10^{+} \mathrm{TGF}-\beta 1^{+}$ Bregs, which subsequently release anti-inflammatory IL-10 and TGF- $\beta 1$. These 2 important molecules lead to the increase in Tregs. These results suggest that Bregs, Tregs, IL-10 (both total levels and cellular), and cellular TGF- $\beta 1$ (not the total level of TGF- $\beta 1$ ) could be used a serial markers for prognosis and monitoring parameters during immunosuppressive treatment of patients with $\mathrm{BO}$ after lung transplantation. These cells and molecules could be used together in the targeted treatment of patients with BO after lung transplantation.

\section{Conflict of Interest Statement}

Authors have nothing to disclose with regard to commercial support.

You can watch a Webcast of this AATS meeting presentation by going to: http://webcast.aats.org/2015/Video/ Tuesday/04-28-15_613_0800_Zhao.mp4.

\section{References}

1. Granton J. Update of early respiratory failure in the lung transplant recipient. Curr Opin Crit Care. 2006;12:19-24.

2. Bhorade SM, Stern E. Immunosuppression for lung transplantation. Proc Am Thorac Soc. 2009; 6:47-53.

3. Chan A, Allen R. Bronchiolitis obliterans: an update. Curr Opin Pulm Med. 2004;10:133-41.

4. Jaramillo A, Naziruddin B, Zhang L, Reznik SI, Smith MA, Aloush AA, et al. Activation of human airway epithelial cells by non-HLA antibodies developed after lung transplantation: a potential etiological factor for bronchiolitis obliterans syndrome. Transplantation. 2001;71:966-76.

5. McDyer JF. Human and murine obliterative bronchiolitis in transplant. Proc Am Thorac Soc. 2007;4:37-43.

6. Zhao Y, LaPar DJ, Steidle J, Emaminia A, Kron IL, Ailawadi G, et al. Adenosine signaling via the adenosine $2 \mathrm{~B}$ receptor is involved in bronchiolitis obliterans development. J Heart Lung Transplant. 2010;29:1405-14.

7. Lau CL, Zhao Y, Kron IL, Stoler MH, Laubach VE, Ailawadi G, et al. The role of adenosine A2A receptor signaling in bronchiolitis obliterans. Ann Thorac Surg. 2009;88:1071-8.

8. Nusair S, Or R, Junadi S, Amir G, Breuer R. Simultaneous donor marrow cell transplantation with reduced intensity conditioning prevents tracheal allograft obliteration in a bronchiolitis obliterans murine model. Chest. 2005;128:4024-9.
9. Lama VN, Harada H, Badri LN, Flint A, Hogaboam CM, McKenzie A, et al Obligatory role for interleukin-13 in obstructive lesion development in airway allografts. Am J Pathol. 2006;169:47-60.

10. Gillen JR, Zhao Y, Harris DA, Lapar DJ, Stone ML, Fernandez LG, et al. Rapamycin blocks fibrocyte migration and attenuates bronchiolitis obliterans in a murine model. Ann Thorac Surg. 2013;95:1768-75.

11. Gillen JR, Zhao Y, Harris DA, Lapar DJ, Kron IL, Lau CL. Short-course rapamycin treatment preserves airway epithelium and protects against bronchiolitis obliterans. Ann Thorac Surg. 2013;96:464-72.

12. LeBien TW, Tedder TF. B lymphocytes: how they develop and function. Blood. 2008;112:1570-80.

13. DiLillo DJ, Hamaguchi Y, Ueda Y, Yang K, Uchida J, Haas KM, et al. Maintenance of long-lived plasma cells and serological memory despite mature and memory B cell depletion during CD20 immunotherapy in mice. $J$ Immunol. 2008;180:361-71.

14. Fillatreau S, Sweenie CH, McGeachy MJ, Gray D, Anderton SM. B cells regulate autoimmunity by provision of IL-10. Nat Immunol. 2002:3:944-50.

15. Matsushita T, Yanaba K, Bouaziz JD, Fujimoto M, Tedder TF. Regulatory B cells inhibit EAE initiation in mice while other B cells promote disease progression. $J$ Clin Invest. 2008;118:3420-30.

16. Fillatreau S, Gray D, Anderton SM. Not always the bad guys: B cells as regulators of autoimmune pathology. Nat Rev Immunol. 2008;8:391-7.

17. Mizoguchi A, Bhan AK. A case for regulatory B cells. J Immunol. 2006;176: 705-10.

18. Mizoguchi A, Mizoguchi E, Takedatsu H, Blumberg RS, Bhan AK. Chronic in testinal inflammatory condition generates IL-10-producing regulatory B cell subset characterized by CD1d upregulation. Immunity. 2002;16:219-30.

19. Mauri C, Ehrenstein MR. The 'short' history of regulatory B cells. Trends Immunol. 2008;29:34-40.

20. Lund FE. Cytokine-producing B lymphocytes-key regulators of immunity. Curr Opin Immunol. 2008;20:332-8.

21. Bouaziz JD, Yanaba K, Tedder TF. Regulatory B cells as inhibitors of immune responses and inflammation. Immunol Rev. 2008;224:201-14.

22. Yanaba K, Bouaziz JD, Haas KM, Poe JC, Fujimoto M, Tedder TF. A regulatory B cell subset with a unique CD1dhiCD5+ phenotype controls T cell-dependent inflammatory responses. Immunity. 2008;28:639-50.

23. Mauri C, Bosma A. Immune regulatory function of B cells. Annu Rev Immunol. 2012;30:221-41.

24. DiLillo DJ, Matsushita T, Tedder TF. B10 cells and regulatory B cells balance immune responses during inflammation, autoimmunity, cancer. Ann N Y Acad Sci. 2010;1183:38-57.

25. Pistoia V. Production of cytokines by human B cells in health and disease. Immu nol Today. 1997;18:343-50.

26. Yang M, Rui K, Wang S, Lu L. Regulatory B cells in autoimmune diseases. Cell Mol Immunol. 2013;10:122-32.

27. Zhao Y, Gillen JR, Harris DA, Kron IL, Murphy MP, Lau CL. Treatment with placenta-derived mesenchymal stem cells mitigates development of bronchiolitis obliterans in a murine model. J Thorac Cardiovasc Surg. 2014;147:1668-77.e5.

28. Zhao Y, Steidle JF, Upchurch GR, Kron IL, Lau CL. Prevention of the second stage of epithelial loss is a potential novel treatment for bronchiolitis obliterans. J Thorac Cardiovasc Surg. 2013;145:940-7.

29. Sato M, Keshavjee S, Liu M. Translational research: animal models of obliterative bronchiolitis after lung transplantation. Am J Transplant. 2009;9:1981-7.

30. Heidt S, Hester J, Shankar S, Friend PJ, Wood KJ. B cell repopulation after alemtuzumab induction-transient increase in transitional B cells and long-term dominance of naive B cells. Am J Transplant. 2012;12:1784-92.

31. McManigle W, Pavlisko EN, Martinu T. Acute cellular and antibody-mediated allograft rejection. Semin Respir Crit Care Med. 2013;34:320-35.

32. Liu HX, Li Y, Zhao CH, Liu Y, Zhang QG, Cong W, et al. [The role of transforming growth factor-beta1/Smad3 signaling in bronchiolitis obliterans following lung transplantation]. Zhonghua Yi Xue Za Zhi. 2007;87:2069-73.

33. Schliesser U, Chopra M, Beilhack A, Appelt C, Vogel S, Schumann J, et al Generation of highly effective and stable murine alloreactive Treg cells by combined anti-CD4 mAb, TGF-beta, RA treatment. Eur J Immunol. 2013;43: 3291-305.

34. Sacher VY, Fertel D, Srivastava K, Panos A, Nguyen D, Baxter T, et al. Effects of prophylactic use of sirolimus on bronchiolitis obliterans syndrome development in lung transplant recipients. Ann Thorac Surg. 2014;97:268-74.

35. Chen JF, Gao J, Zhang D, Wang ZH, Zhu JY. CD4+Foxp3+ regulatory T cells converted by rapamycin from peripheral $\mathrm{CD} 4+\mathrm{CD} 25(-)$ naive $\mathrm{T}$ cells display more potent regulatory ability in vitro. Chin Med J (Engl). 2010;123:942-8. 
36. Prevel N, Allenbach Y, Klatzmann D, Salomon B, Benveniste O. Beneficial role of rapamycin in experimental autoimmune myositis. PLoS One. 2013;8:e74450.

37. Singh AK, Seavey CN, Horvath KA, Mohiuddin MM. Ex-vivo expanded baboon CD4+ CD25 Hi Treg cells suppress baboon anti-pig T and B cell immune response. Xenotransplantation. 2012;19:102-11.

38. Knechtle SJ. Immunoregulation and tolerance. Transplant Proc. 2010;42:S13-15.

39. Blair PA, Chavez-Rueda KA, Evans JG, Shlomchik MJ, Eddaoudi A, Isenberg DA, et al. Selective targeting of B cells with agonistic anti-CD40 is an efficacious strategy for the generation of induced regulatory T2-like B cells and for the suppression of lupus in MRL/lpr mice. J Immunol. 2009;182: 3492-502.

40. Walters S, Webster KE, Sutherland A, Gardam S, Groom J, Liuwantara D, et al. Increased CD4+Foxp3 $+\mathrm{T}$ cells in BAFF-transgenic mice suppress $\mathrm{T}$ cell effector responses. J Immunol. 2009;182:793-801.

41. Carter NA, Vasconcellos R, Rosser EC, Tulone C, Munoz-Suano A, Kamanaka M, et al. Mice lacking endogenous IL-10-producing regulatory B cells develop exacerbated disease and present with an increased frequency of Th1/ Th17 but a decrease in regulatory T cells. J Immunol. 2011;186:5569-79.

42. Ray A, Basu S, Williams CB, Salzman NH, Dittel BN. A novel IL-10independent regulatory role for B cells in suppressing autoimmunity by maintenance of regulatory T cells via GITR ligand. J Immunol. 2012;188:3188-98.

43. Genden EM, Boros P, Liu J, Bromberg JS, Mayer L. Orthotopic tracheal transplantation in the murine model. Transplantation. 2002;73:1420-5.

44. Okazaki M, Krupnick AS, Kornfeld CG, Lai JM, Ritter JH, Richardson SB, et al. A mouse model of orthotopic vascularized aerated lung transplantation. Am J Transplant. 2007; 7:1672-9.

Key Words: bronchiolitis obliterans, rapamycin, regulatory B lymphocytes, mouse heterotopic tracheal transplant, FoxP3 $\beta$ regulatory $\mathrm{T}$ cells

\section{Discussion}

Dr S. M. Pham (Baltimore, $M d$ ). You should be congratulated for these novel findings. It has been thought that the antifibrotic property of rapamycin is responsible for the prevention of $\mathrm{BO}$, but certainly what you presented today is a new exciting mechanism. However, from the scientific point of view, to make sure that this is the true mechanism, one has to perform the so-called gain-and-loss-of-function studies where you deplete the B cells or infuse the Breg cells into the animals to see if you still get the same or similar results. Recently, it has been shown that you can expand the Breg cells ex vivo. Have you tried to deplete the Breg cells or reinfuse the Breg cells in your model and see if there is any difference in the development of $\mathrm{BO}$ ?

Dr Zhao. This is a great suggestion. Our study is still preliminary, and we have not tried the gain-and-loss-offunction of the B cells, but we are thinking about using B-cell-deficient mice to get the loss-of-function phenotype, and then we will infuse B cells from the wild-type mice back into the B-cell-deficient mice to get the gain of function. In addition, we may confirm this with IL-10 knockout mice. We will isolate B cells from IL-10 knockout mice and then transfer back to the B-cell-deficient mice. If it is not working, it will be a confirmation. Another way, as you suggested, is to use the ex vivo expanded Breg cells and then reinfuse them into the knockout mice to see what will happen in our future experiments.

Dr Pham. As you know, rapamycin clinically increases the incidence of bronchial anastomotic dehiscence, so we could not use that drug early on after transplant. We and others have shown that if we introduce the drug late in the post-transplant period, in combination with a calcineurin inhibitor and low-dose steroids, we are able to effectively prevent or delay the development of BO. When we use rapamycin clinically like that, do you think the mechanism of action of rapamycin is similar to what you see in your model? On the basis of all the studies you have done, what would be the optimal use of that drug clinically in lung transplantation?

Dr Zhao. For the first question, I don't know whether the mechanism in our finding in the mouse model can be applied to the patient. We hope that is the case. In recent findings it was seen that humans also have the Breg cells. It's possible that the findings we got from mice will apply to the patient. It is possible both mice and humans share a similar mechanism. It will be interesting to have more studies and to confirm if this works the same way in patients as in the mice.

For the second question, according to our study, we can suggest using a low dosage at the beginning and a high dosage of rapamycin in the late stage. According to our experiment, we use an on-and-off mechanism. For example, we treat the mice from day 3 to day 7 and then we stop treatment, and back on treatment again 1 week later, we got similar effects. It is not as obvious as continuing treatment for 2 weeks, but it still has the antifibrotic function. Therefore, using rapamycin for 1 week and off for another week may work in clinics. Another possibility is to use the combination therapy, as you suggested, use rapamycin with the calcineurin inhibitor and the low-dose steroids, or use IL21 , which is a key activator for Breg cells with the low dosage of rapamycin. 


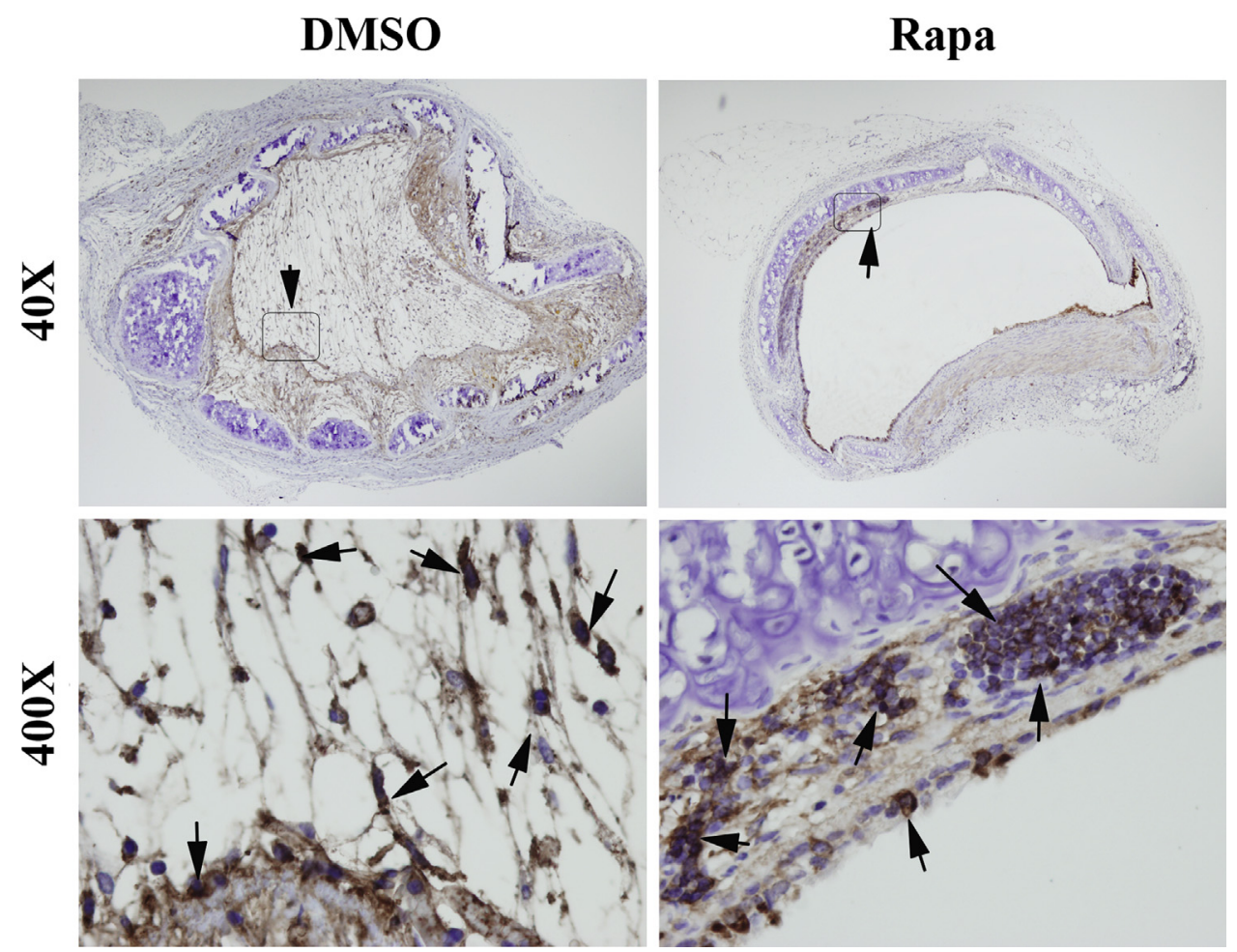

FIGURE E1. Representative immunostaining picture of TGF- $\beta 1^{+}$cells in the allografts with DMSO controls on day 28 . Brown/dark brown indicate TGF$\beta 1^{+}$cells. All sections were counterstained lightly with hematoxylin for viewing negatively stained cells. The magnifications are indicated. The solid arrows in the top panel indicate the amplified area in the bottom panel. The solid arrows in the bottom panel indicate the TGF- $\beta 1$-positive cells. DMSO, Dimethyl sulfoxide; Rapa, rapamycin. 

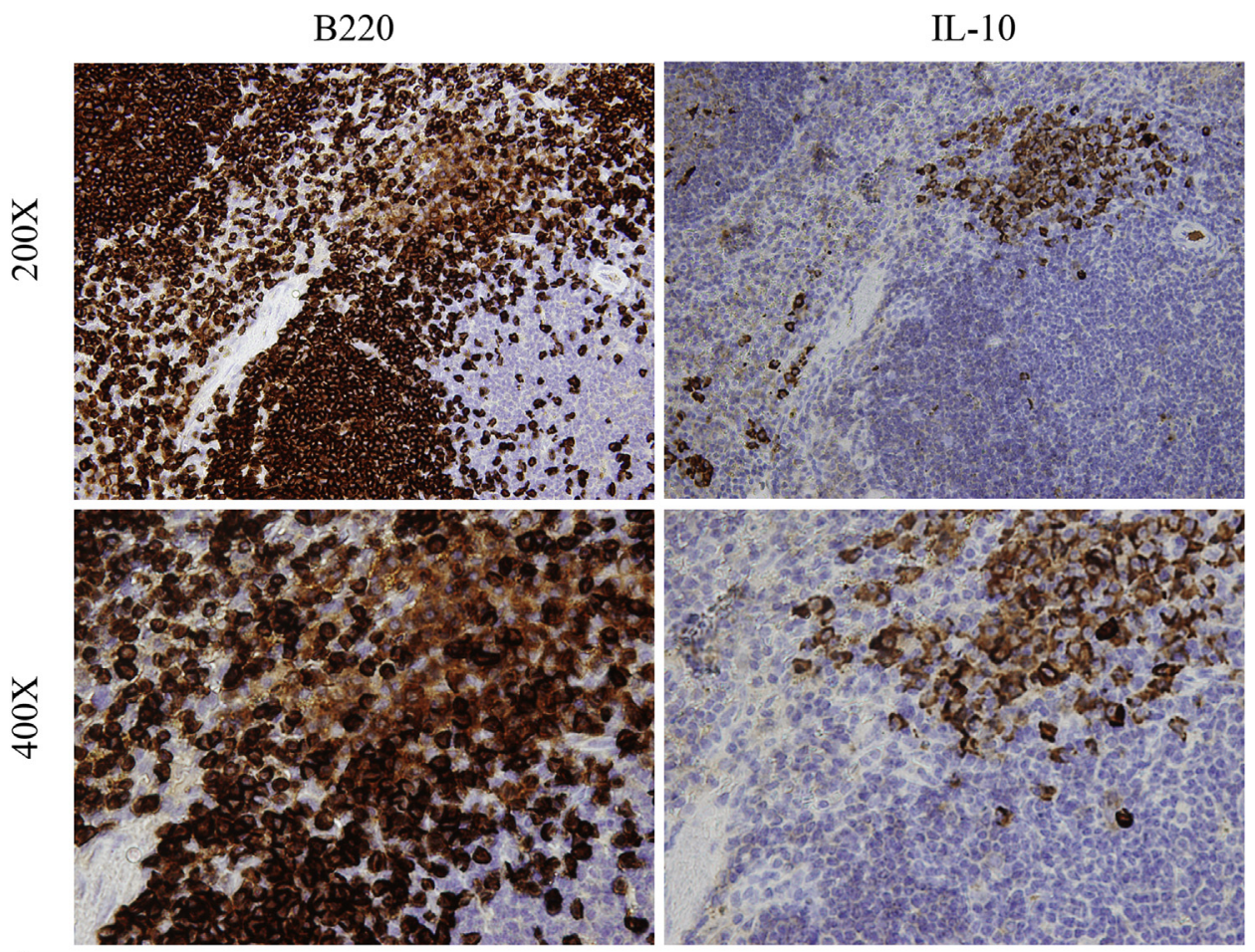

A

B220
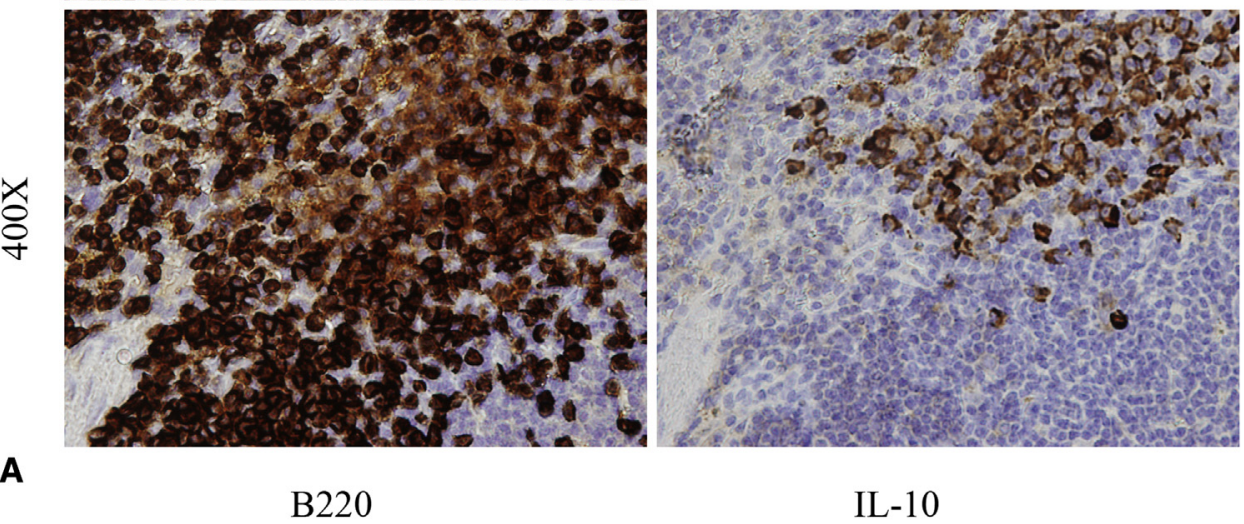

IL-10
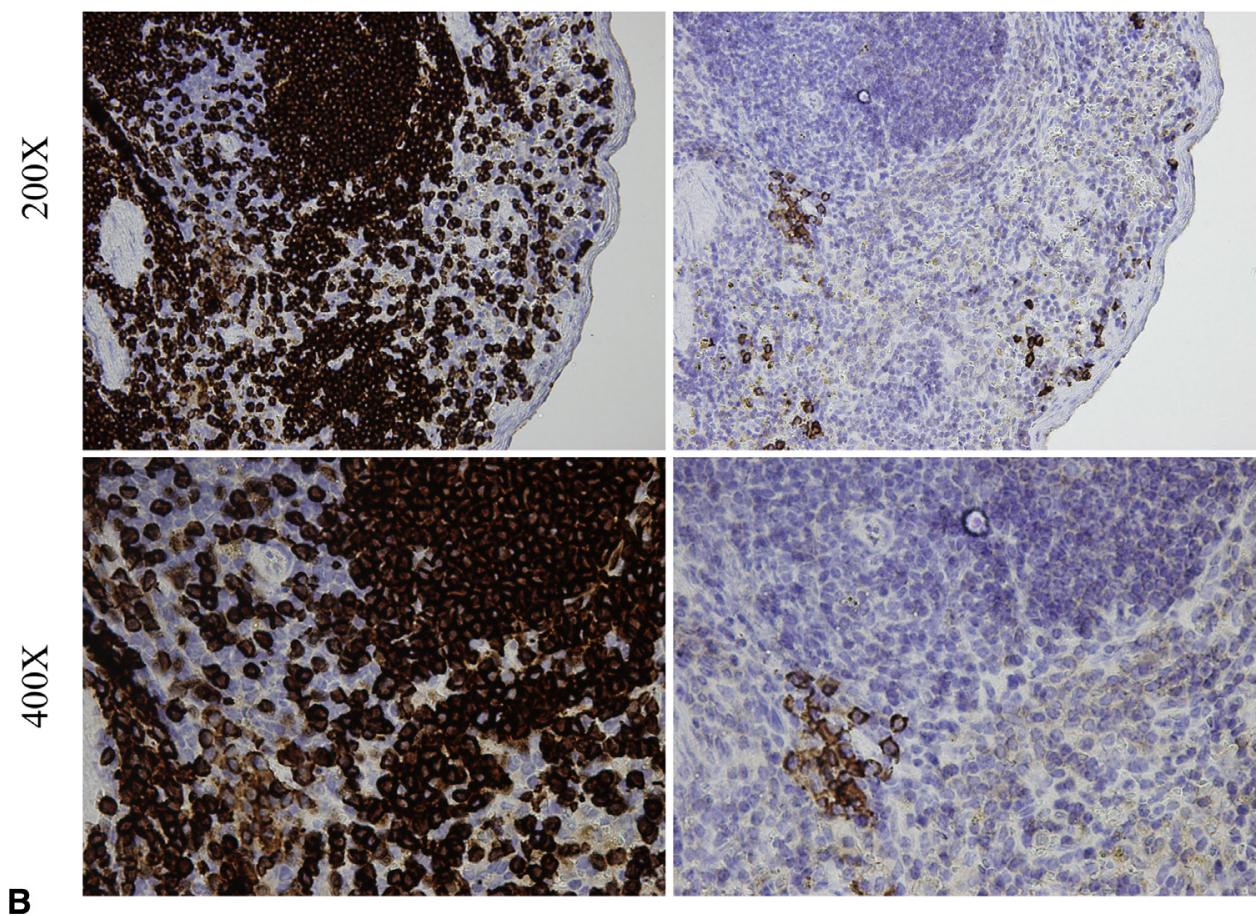

FIGURE E2. Immunohistochemical staining of $\mathrm{B} 220^{+}$and IL- $10^{+} \mathrm{B}$ cells in the spleens of recipients on day 28 after tracheal transplantation. A, Representative immunostaining picture of $\mathrm{B} 220^{+}$and IL- $10^{+} \mathrm{B}$ cells in the spleen of DMSO-treated recipients. Representative immunostaining picture of B220 and $\mathrm{IL}-10^{+} \mathrm{B}$ cells in the spleen of DMSO-treated recipients. B, Representative immunostaining picture of B220 $0^{+}$and IL- $10^{+} \mathrm{B}$ cells in the spleen of rapamycin-treated recipients. Brown/dark brown indicate B220 or IL- $10^{+} \mathrm{B}$ cells. All sections were counterstained lightly with hematoxylin for viewing negatively stained cells. The magnifications are indicated. $I L$, Interleukin. 


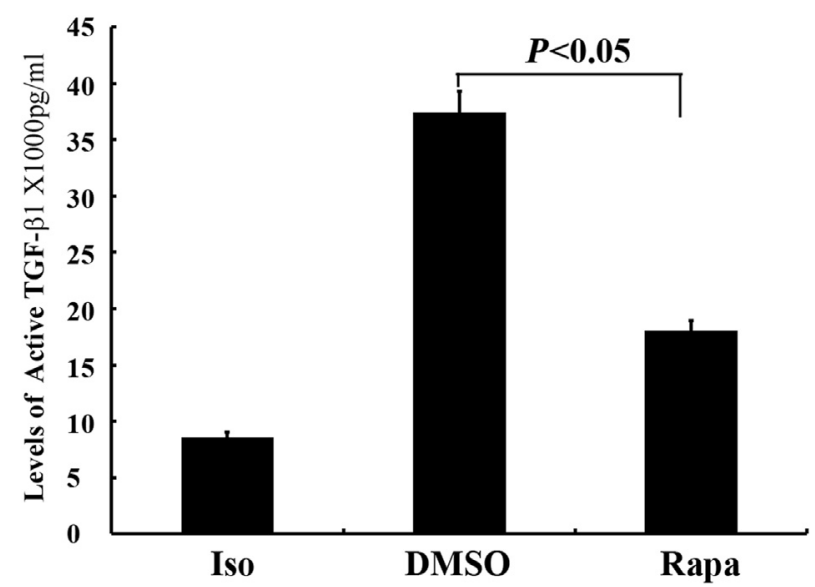

FIGURE E3. Levels of active TGF- $\beta 1$ in the allografts and isografts on day 28. Luminex assay was performed using the Bio-Plex 200 system with standard controls. The concentration is $\mathrm{pg} / \mathrm{ml}$. Data shown are the mean \pm standard deviation, $\mathrm{n}=6$. Iso, Isograft; $D M S O$, dimethyl sulfoxide; Rapa, rapamycin; $T G F$, transforming growth factor. 